\title{
HIV Prevention Using Films: HIV/AIDS Positive African American Women Respond through Interpersonal Relationships in Life Support
}

\author{
DaKysha Moore ${ }^{1 *}$, Elijah 0. Onsomu ${ }^{2 *}$, Benta A. Abuya ${ }^{3}$ \\ ${ }^{1}$ Department of Visual, Performing and Communication Arts, Johnson C. Smith University, Charlotte, NC, USA \\ ${ }^{2}$ Division of Nursing, Winston-Salem State University, Winston-Salem, NC, USA \\ ${ }^{3}$ Education Research Program, African Population and Health Research Center (APHRC), Nairobi, Kenya \\ Email: damoore@jcsu.edu , ${ }^{*}$ oonsomu@gmail.com
}

Received 24 September2014; revised 25 October 2014; accepted 2 November 2014

Copyright () 2014 by authors and Scientific Research Publishing Inc.

This work is licensed under the Creative Commons Attribution International License (CC BY).

http://creativecommons.org/licenses/by/4.0/

c) (i) Open Access

\begin{abstract}
HIV/AIDS has had a profound effect on the African American community. According to the Centers for Disease Control and Prevention [1], in 2010, African American women accounted for more than $25 \%$ of new HIV cases among Blacks. This staggering statistic has sparked social campaigns, including films that aim to address or hinder the spread of HIV. The film Life Support focuses on the social issues that shape the lives of African American women with HIV/AIDS. This study analyzed the film using Black feminist thought as the conceptual framework for understanding the everyday experiences of the main character, Ana, related to contracting the disease, stigma, sexuality, support systems, and coping mechanisms. It shows that knowledge is an important tool for living and coping with the disease. Additionally, it explores the image of HIV/AIDS among African American women. The film's themes include Ana as a change agent, Life Support conversations, and positive and negative relationships.
\end{abstract}

\section{Keywords}

African American Women, Films, Framing Analysis, HIV/AIDS, Life Support, Social Change

\section{African American Women and HIV/AIDS}

HIV/AIDS rates among both men and women represent a health crisis and a serious health disparity. According to the Centers for Disease Control and Prevention [1], in 2010, African Americans represented almost 44\% of ${ }^{*}$ Corresponding authors.

How to cite this paper: Moore, D., Onsomu, E.O. and Abuya, B.A. (2014) HIV Prevention Using Films: HIV/AIDS Positive African American Women Respond through Interpersonal Relationships in Life Support. Open Journal of Social Sciences, 2, 110-118. http://dx.doi.org/10.4236/jss.2014.211016 
new HIV infections in the United States; African American women represented approximately $29 \%$ of this figure [2]. While these rates were lower than those recorded in 2008, African American women are still twenty times more likely to be infected than White women and five times more likely than Latinas [1]. The need to demonstrate to the public how HIV/AIDS has changed the lives of countless African American women is both obvious and urgent.

One of the main modes of HIV transmission for African American women is unprotected sex with a person who is HIV positive. The women may not know their partners who have had unprotected sex with several partners, sex with men, or injected illegal drugs, all risk factors for HIV [2]. According to Mondanaro [3], even if women are not intravenous drug abusers, their partners may be, which increases their risk for contracting the disease.

Because HIV/AIDS has such a detrimental impact on African American women, discussions about the disease's effects should continue. In 2007, HBO released a film entitled Life Support that focuses on an African American woman, Ana, who is HIV positive [4]. The purpose of this paper is to interpret the social construction of HIV/AIDS among African American women in the film Life Support. Using Patricia Hill Collins's conceptual framework Black feminist thought [5]; the researchers explored the everyday experiences of the character Ana and her associates to understand HIV/AIDS among African American women.

\section{The Media as a Source of HIV/AIDS Information}

Strategic health communication campaigns have been essential for raising awareness of HIV risk factors [6]. Public health and communication practitioners have used the mass media, including television, radio, and the Internet, and various forms of print media, such as billboards, magazines, and newspapers, to halt the spread of HIV/AIDS.

One strategy is entertainment education (E-E), which uses the media to both entertain and educate the public about a problem. It does more than increase awareness; practitioners use the messages to help the target audience practice more favorable behaviors [7]. According to Singhal and Vasanti [8] the E-E strategy can prompt social change by fostering positive attitudes, creating more awareness about a social issue, and creating an environment for positive change. Singhal and Rogers [9] note, “... the general purpose of entertainment-education interventions is to contribute to the process of directed social change, which can occur at the level of an individual, community, or society" (p. 5). People are more likely to discuss events in a media story than their own personal lives. Educational programming may provide a safe "point of reference" that makes people more at ease in talking about such restricted topics as sex and drugs [7]. A study by Onsomu, Moore, Abuya, Valentine, and Duren-Winfield [10] found that media (television, radio, newspapers, and magazines) were an important tool in scaling-up HIV testing in Kenya. While Signorielli [11] showed that the media do not always illustrate such issues as drug effects, unwanted pregnancy, and sexually transmitted diseases correctly, they are still important in helping people to decide how they perceive society [12].

Many have criticized the media's reluctance to tackle HIV/AIDS, including the film industry. One of the most popular US film to portray AIDS was Philadelphia [8], a vivid depiction of the daily struggles and prejudices a HIV-positive person encounters. International films that educate and raise awareness about HIV/AIDS include Phir Milenge in India [8] and South African documentaries, such as AIDS: A Union Issue [13] and Yesterday (2004) a film based on AIDS in South Africa.

In the US and other countries, some are concerned that the problem of HIV/AIDS among women has been marginalized, and this criticism extends to the media. According to Kitzinger [14], media representation of HIV/AIDS among women includes both good and bad images centered on "female sexuality". Of the very few movies focused on HIV/AIDS among women in the US, Boys on the Side (1995) used the plot convention of three women driving across country. Robin, a middle-class White woman, is HIV positive. Waites ([15] p. 485) discusses that the movie does not emphasize the "medical or socio-political context" or the cultural nuances of HIV.

In 2007, HBO released Life Support, which focuses on an African American woman who is HIV positive. Ana struggles with relationships with various family members, such as her mother and oldest daughter. She works for an HIV/AIDS outreach group where she helps and counsels people who are HIV/AIDS positive or may be at greater risk of contracting the disease. A scholarly examination of the movie is important because it is one of the first to focus strictly on HIV/AIDS in the African American community and might serve as an educa- 
tion tool to convey the seriousness of the problem.

\section{Theoretical Framework: Black Feminist Thought}

Due to the social issues that may hinder the Black community from addressing various issues on HIV/AIDS such as stigma about same sex relationships, high rates of incarceration among Black men, and poverty, this discussion require a theory that captures the essence of a Black woman's experiences. Julia T. Wood [16] uses feminist standpoint theory to explain how the social group co-creates an individual's identity. A main tenet holds that men and women do not have the same experiences, which leads to different types of knowledge. Consequently, this study will use Patricia H. Collins's critical/interpretive framework Black feminist thought [5], which is rooted in the African American woman's standpoint.

Collins explores how Black women's everyday activities and interactions shape their image and create their epistemologies, which are grounded in "oppression". An important premise is that through knowledge, Black women gain power. The concept of Black feminism is not defined by all-inclusive theories but focuses on the Black woman and her unique daily experiences [17]. Collins [5] writes, "I suggest that Black feminist thought consists of specialized knowledge created by African-American women which clarifies a standpoint of and for Black women. In other words, Black feminist thought encompasses theoretical interpretations of Black women's reality by those who live it” (p. 22). In the past, Black feminist thought has been used to gain insights about the high-risk behaviors that increase Black women's risk of contracting HIV/AIDS [18]. The researchers used Black feminist thought to understand the salient themes of the film Life Support, which are socially constructed through the character Ana and her relationships with family and friends.

\section{Methodology}

The researchers viewed the movie Life Support several times, focusing on themes made apparent throughout the discourse. The character Ana is present in most scenes, and the researchers were able to gain a clear picture of her and her interactions with other characters. They sought to answer the following research questions:

RQ1: What salient themes of the film Life Support are socially constructed through the character Ana?

RQ2: What salient themes of the film Life Support are socially constructed through Ana's family and friends?

To best answer these questions, they used a framing analysis. According to Entman ([19] p. 52), "Frames, then, define problems - determine what a causal agent is doing with what costs and benefits, usually measured in terms of common cultural values; diagnose causes-identify the forces creating the problem; make moral judgments — evaluate causal agents and their effects; and suggest remedies—offer and justify treatments for the problems and predict their likely effects". Jasperson, Shah, Watts, Faber, and Fan [20] find a framework is especially useful for understanding the "power of communication" in media images and the mental process of interpreting events. Frames are critical for analyzing media discourse [21]. Gamson ([22] p. 159) writes about the importance of having pictures in television news: "Frame analysis helps to solve the problem of what visual cues are important and meaningful. The visual content, like the words, takes on meaning from the framing context”. Framing analysis has been used in several other research studies to understand media messages [23]. In this study, the researchers explored patterns in the film and identified several themes related to the basic social issues of HIV/AIDS in the African American community.

\section{Results}

\subsection{Ann the Change Agent}

In the diffusion of innovations, Rogers [24] discusses the important role of a change agent in getting people to adopt new behaviors or introducing them to new products. In addition, the change agent is influential in ensuring that the adopters can carry out the new behaviors properly. In Life Support, Ana is a change agent for her community. She is an HIV-positive African American woman who works for an HIV/AIDS outreach group called Life Support. The researchers were not clear whether Ana contracted the virus through her intravenous drug use or if she was infected through unprotected sex with her husband Slick, who is also HIV positive and a former intravenous drug user. In spite of Ana's medical condition, she walks the streets of New York City tirelessly, passing out condoms to people who are homeless and at greater risk for contracting the virus. She is strongly committed to her role as an HIV/AIDS activist. She also tries to raise people's self-efficacy levels to help them 
engage in healthy behaviors and to take an HIV/AIDS test, so they can know their status.

A second characteristic of a change agent is fostering and cultivating relationships with clients. Important attributes in developing relationships with clients are "trustworthiness and empathy" [24]. In this respect, Ana embodies the change agent. According to Rogers, change agents usually have completed college and are skilled in a specific area, but because Ana is HIV positive, her extensive knowledge comes from her experiences. The movie shows that the people with whom she interacts in the context of the streets and the outreach center respect her judgment. She is able to have serious conversations about lifestyle choices with characters who are HIV/ AIDS positive, drug abusers, and women from different socioeconomic levels. Furthermore, she is very open and understanding about the situations of the people she works with. As an ideal change agent, she is respected by the community she is trying to change. By working at the HIV/AIDS outreach center, she helps to develop change, and she can communicate convincing messages about practicing safer behaviors because of her relationships with clients and members of the surrounding communities.

Change agents are usually educators or public health workers who function as a conduit between "resource systems and clients" [24]. However, Black women who do not serve in these roles can still act as change agents in their communities because HIV/AIDS has become one of main causes of death for African American women [25]. By joining organizations that address HIV/AIDS, they can better educate other women in their church community, at colleges and universities, sororities, hair salons, and other common venues that attract Black women. Like Ana, African American women can start empowering themselves by educating other Black women. Black women who are change agents can use their personal relationships to keep HIV/AIDS in the consciousness of Black women by stressing the importance of using condoms all the time and not engaging in other behaviors that increase HIV/AIDS risk.

\subsection{Life Support Conversations: A Source of Open Dialogue for Black Women}

In the film's first scene, African American women sitting in a support group discuss how they contracted HIV, for reasons ranging from sexual contact to injecting illegal drugs [26]. The women tell viewers their stories and share their mistakes. One says she knowingly dated a man who injected illegal drugs. Another says the condoms were in the room, and they decided to not use them.

Reading the women's comments might make them seem powerless and oppressed in their relationships. A sense of powerlessness may have facilitated the behaviors that led to their HIV/AIDS status, but they have reclaimed their power by participating in the group sessions. Hooks [27] points out that many Black women from all walks of life suffer from addictions, especially during a stressful phase. These addictions can take the form of drugs or even shopping/overspending; however, she emphasizes that women can use the virtues of "self-discovery" and "self-esteem" to counteract them and enjoy a fulfilling life. The women in the film are now helping others who are less empowered by sharing their stories.

The women's discourse quickly engages viewers to consider transmission modes that include intravenous drug use, sex with a partner who injects illegal drugs, and sex without condoms. According to both the CDC [28] and the Kaiser Family Foundation [29], the main modes of HIV transmission for both White and Black women are heterosexual activity and intravenous drug use. Recent numbers from the CDC show that of new HIV cases among women, more than $80 \%$ were contracted through heterosexual engagement [2]. The women in the film also discuss topics ranging from judging a man by his appearance to the difficulties of telling partners about a HIV-positive result [26].

Conversations at the Life Support center also inform the public about the importance of HIV/AIDS support groups, counseling, and using condoms. One important discussion is on the use of female condoms, which, in the United States at least, are very seldom promoted. The women discuss how to properly use them and the ease of using them before sexual intercourse. One woman talks about the difficulty of getting younger Black women to use them [26]. Keeping condom discussions in the media is important. Studies show that many African American women do not consistently ensure that their male partners wear condoms during sexual intercourse. Female condoms could help them to negotiate safer sex practices [30] Shervington [31] found that African American women with lower incomes were willing to use condoms; many expressed concerns about getting their partners to use condoms and felt the female condom helped them to protect themselves from unwanted consequences. The female condom can be a tool not only to protect but to empower sexually active women [32]. 


\subsection{African Americans Might Be Afraid and Ashamed of HIV/AIDS}

Since the HIV/AIDS epidemic began, Americans have become more knowledgeable about the disease, but Herek and Capitanio [33] found some research participants did not feel comfortable interacting with people with AIDS (PWA), including touching their clothing or drinking from the same cup. In the film, a scene shows stigma and discrimination, as the boyfriend of Ana's teenage daughter, Kelly, asks her why her mother walks around handing out condoms. Kelly replies that her mother works for an AIDS outreach program. The boyfriend responds, "I couldn't do it, you know, be around them people all the time. I would be like paranoid”. Kelly replies, "Yeah”, and does not tell him about her mother's HIV status [26]. The scene clearly shows that the boyfriend does not have positive attitudes toward people with the disease.

Other characters also discuss discrimination toward them in their day-to-day encounters. The character Ness is shown at a church group meeting, discussing his encounter with a clerk while trying to get his medication. The fear of being exposed to the virus through touch or casual contact is not uncommon. According to a report from the Kaiser Family Foundation [34], slightly more than 15\% of minorities who participated in a study thought an individual could contract HIV through “touching a toilet seat after an infected person”, and more than third indicated that kissing is a transmission mode. Herek, Capitanio, and Widaman [35] found that, in 1997, almost 30\% of their respondents felt that people who were HIV positive "got what they deserved", but by 1999 , attitudes toward PWAs had become more positive.

Attitudes toward HIV/AIDS patients are linked to the level of social stigma they encounter. External social pressures may have driven off family members [36]. Kelly's good friend Amare is HIV positive, very sick, and refuses to take his medication. He is living on the streets because his parents have died after contracting HIV/ AIDS through drug use, and his sister, Tanya, and her husband have put him out of the house. Amare is shown sitting outside on a bench staring at his sister's window. Ana notices that Amare is very sick and might not survive, she goes to Tanya's apartment and begs her to open the door, but she does not [26]. Tanya's reactions to Amare’s illness are common. Lloyd ([36] p. 188) writes: "Family members must come to terms with their feelings about the way the infection was contracted, and with their own and society's view on homosexuality, prostitution, drug abuse, promiscuity, and infidelity”. The film illustrates the very negative attitudes toward PWAs in the African American community.

The film also addresses the fear and violence that can accompany telling a partner that one is positive. HIV/ AIDS affects marginalized groups, and violent behaviors, such as forced sex, are another risk for these women. Maman, Mbwambo, Hogan et al. [37] found that, in Africa, HIV positive women were more likely to have a violent partner. In the film, the character Deyah Kingston is pregnant and HIV positive. Ana stresses the importance of informing her husband about her status, but he kills Deyah [26]. Violence against HIV-positive women is not uncommon. Research in African countries found that women who are HIV positive may delay informing their partners because they fear physical abuse. This fear, in turn, may delay their treatment [38]. This problem is also shown in the HBO film Yesterday (2004).

\subsection{Denial}

A subtheme throughout the movie is denial. Some of the women thought that they could not contract the disease. Women in the support group say that they felt they could not be infected by the HIV virus until they tested positive for the disease. A Kaiser Family Foundation survey [34] found that the level of concern about becoming HIV positive decreased from 1991 through 2006.

Denial is also expressed through the relationship between Amare and Michael. Michael has a wife and children and denies having had a romantic relationship with Amare. The dynamics of the relationship between the two characters are not uncommon in the African American community. Millet, Malebranche, Mason, and Spikes [39] found that Black males are less likely to admit to a bisexual or same-sex relationship than other race/ethnic group members. Concealing same-sex relationships can put Black females at risk for contracting the HIV virus [40].

\subsection{Positive Relationships}

The HIV/AIDS epidemic does not affect only those who contract the disease. Family members must also deal with negative medical, emotional and social effects [41]. In spite of the hardships of living with HIV/AIDS, the 
relationships between Amare and Kelly, Kim and Ana, and Slick and Ana are of loving. Amare and Kelly’s relationship is based on a childhood friendship that deepened because their respective parents abused drugs.

Ana and her youngest daughter, Kim, have a very positive relationship. Kim is 10 and HIV negative because Ana took her medication during pregnancy. Kim clearly understands that her mother is HIV positive. Ana takes Kim to various professional sporting events with members of the Life Support organization [26]. Yarhouse [42] conducted case studies and found that support groups are important for families of PWAs. Engaging with other HIV positive families can offer comfort and "coping strategies".

Another important positive relationship in the film is between Slick and Ana. Even though the relationship is strained because both are HIV positive, several scenes show their compassion toward each other, taking care of each other physically and emotionally.

\subsection{Negative Relationships}

Even supportive families experience some type of disruption due to the financial strain of the disease, feelings of social stigma, or the behaviors that caused the individual to become HIV positive [36]. Ana's relationship with Kelly is civil but troubled. Kelly seems to resent her mother for contracting the disease and not being present during her childhood years. She clearly blames Ana for the behaviors that led to the disease [26]. Children often have negative reactions to their mother's HIV positive status. Vallerand, Hough, Pittiglio, and Marvicsin [43] found that most mothers viewed the disclosure of their HIV positive status to their children as less negative, but many children in the study became rebellious after finding out about their mother's status.

The relationship between Ana and her mother is clearly strained. During a conversation between Kelly and her grandmother, the grandmother expresses concern about Kelly coming home late at night [26]. She tells Kelly that she is disappointed in Ana. It is not uncommon for HIV/AIDS to weaken the family bond. The disease's social, physical, and financial effects can be too challenging for some family members. Also, any contributing negative past behaviors (for example, illegal intravenous drug use) may have seeded resentment [44]. The disease makes people acknowledge that their loved one engaged in behaviors that are illegal or culturally unacceptable [36].

\section{Discussion}

Life Support focuses on the daily experiences and struggles of Black women living with HIV/AIDS. Almost all the actors and actresses in the film are African American, one of a few movies emphasizing the physical, cultural, and social impact of the disease in the African American community. Philadelphia (1993), Boys on the Side (1995), and Rent (2005) showed the challenges that HIV/AIDS-positive people face during their daily lives, but they did not show how the disease is socially constructed in the African American community through everyday experiences. Life Support gives good insight into the HIV/AIDS concerns that are paramount among Black women.

The film shows Ana having to take her medication and eventually needing a cane to continue walking around town, passing out HIV/AIDS brochures and condoms. She encounters several social and medical problems trying to take care of herself and her family. Many HIV-positive women are also caregivers. They are responsible for helping to care for their spouse, children, parents, and others and often do not take proper care of themselves [44].

The social construction of HIV/AIDS in Life Support is shaped through the discussions and behaviors of the characters, who portray almost every aspect of the disease that affects the African American community. The only problem that is not addressed is the serious financial hardship the disease places on a family, which is an important discussion. Many HIV patients are already at a socioeconomic disadvantage that affects proper health care [28].

Life Support is a form of entertainment education because it creates meaningful dialogue about a disease associated with behaviors that are sometimes culturally unacceptable. The importance of these types of discussions was shown in Moore, Onsomu, and Abuya's [45] study of reactions to the film Yesterday. Again, entertainment education is crucial because it engages people in discourse about issues that may not be commonly discussed [7]. Scholars such as Michel Foucault believe that knowledge is created through discourse [46].

Films must continue to show the effects of HIV/AIDS in the African American community. Entertainment education through the media can help to shape discourse among African Americans and encourage more discus- 
sions about safe sex and the harm of behaviors, such as intravenous drug abuse. Keeping dialogue open about the conditions that put Black women at greater risk for contracting the disease is important. Through discourse, negative attitudes and stigma associated with HIV/AIDS might be reduced, and more women might be empowered to protect themselves from behaviors that increase their HIV/AIDS risk.

A limitation of this study is that it only applies to the images of HIV-positive African American women and the reactions and behaviors of their friends and families toward the disease in one film. Findings from this film cannot be generalized to other groups, and they clearly stem from the researchers' perspective. Future research should gather Black women' opinions about the film to gauge whether they think differently about the disease after taking in its messages.

\section{References}

[1] Centers for Disease Prevention and Control (2013) HIV among African Americans: Fact Sheet. http://www.cdc.gov/nchhstp/newsroom/docs/CDC-HIV-AA-508.pdf

[2] Centers for Disease Prevention and Control (2013) HIV among Women. http://www.cdc.gov/hiv/risk/gender/women/facts/index.html

[3] Mondanaro, J. (1990) Community-Based AIDS Prevention Interventions. Special Issue of Women Intravenous Drug Users. In: Leukefeld, C.G., Battes, R.J. and Amsel, Z., Eds., AIDS and Intravenous Drug Use: Future Directions for Community-Based Prevention Research, NIDA Research Monograph 93, US Department of Health and Human Services, 68-81. http://www.nida.nih.gov/pdf/monographs/93.pdf\#page=83

[4] HBO Films Life Support (2008) Synopsis. http://www.hbo.com/films/lifesupport/synopsis/index.html

[5] Collins, P.H. (1990) Black Feminist Thought: Knowledge, Consciousness, and the Politics of Empowerment. Unwin Hyman, Inc., Boston.

[6] Maibach, E.W., Kreps, G.L. and Bonaguro, E.W. (1993) Developing Strategic Communication Campaigns for HIV/AIDS Prevention. In: Ratzan, S.C., Ed., AIDS: Effective Health Communication for the 90s, Taylor \& Francis, Washington, DC, 15-35.

[7] Singhal, A. and Rogers, E.M. (2003) Combating AIDS: Communication Strategies in Action. Sage Publications, Thousand Oaks.

[8] Singhal, A. and Vasanti, P.N. (2005) The Role of Popular Narratives in Stimulating the Public Discourse on HIV/AIDS: Bollywood's Answer to Hollywood's Philadelphia. South Asian Popular Culture, 3, 3-15. http://dx.doi.org/10.1080/14746680500118533

[9] Singhal, A. and Rogers, E.M. (2004) The Status of Entertainment-Education Worldwide. In: Singhal, A., Cody, M.J., Rogers, E.M. and Sabido, M., Eds., Entertainment-Education and Social Change: History, Research, and Practice, Lawrence Erlbaum Associates, Mahwah, 3-20.

[10] Onsomu, E.O., Moore, D., Abuya, B.A., Valentine, P. and Duren-Winfield, V. (2013) Importance of the Media in Scaling-Up HIV Testing in Kenya. SAGE Open, 3, 1-12. http://dx.doi.org/10.1177/2158244013497721

[11] Signorielli, N. (1998) Health Images on Television. In: Jackson, L.D. and Duffy, B.K., Eds., Health Communication Research: A Guide to Developments and Directions, Greenwood Press, Westport, 163-180.

[12] Du Pre, A. (2004) Communicating about Health: Current Issues and Perspectives. 2nd Edition, McGraw Hill, Burr Ridge.

[13] Hodes, R. (2007) HIV/AIDS in South African Documentary Film, c. 1990-2000. Journal of Southern African Studies, 33, 153-171. http://dx.doi.org/10.1080/03057070601136673

[14] Kitzinger, J. (1994) Visible and Invisible Women in AIDS Discourses. In: Doyal, L., Naidoo, J. and Wilton, T., Eds., AIDS: Setting a Feminist Agenda, Taylor \& Francis Inc., Bristol, 95-109.

[15] Waites, K.J. (2006) Invisible Woman: Herbert Ross’ Boys on the Side Puts HIV/AIDS and Women in Their Place. The Journal of Popular Culture, 39, 479-492. http://dx.doi.org/10.1111/j.1540-5931.2006.00259.x

[16] Wood, J.T. (2005) Feminist Standpoint Theory and Muted Group Theory: Commonalities and Divergences. Women and Language, 28, 61-64.

[17] Stephens, D.P. and Phillips, L. (2005) Integrating Black Feminist Thought into Conceptual Frameworks of African American Adolescent Women’s Sexual Scripting Processes. Sexualities, Evolution and Gender, 7, 37-55. http://dx.doi.org/10.1080/14616660500112725

[18] Gentry, Q.M. (2007) Black Women’s Risk for HIV: Rough Living. The Hawthorn Press, New York.

[19] Entman, R.M. (1993) Framing: Toward Clarification of a Fractured Paradigm. Journal of Communication, 43, 51-58. http://dx.doi.org/10.1111/j.1460-2466.1993.tb01304.x 
[20] Jasperson, A.E., Shah, D.V., Watts, M., Faber, R.J. and Fan, D.P. (1998) Framing and the Public Agenda: Media Effects on the Importance of the Federal Budget Deficit. Political Communication, 15, 205-224. http://dx.doi.org/10.1080/10584609809342366

[21] Gamson, W.A., Croteau, D., Hoynes, W. and Sasson, T. (1992) Media Images and the Social Construction of Reality. Annual Review of Sociology, 18, 373-393. http://dx.doi.org/10.1146/annurev.so.18.080192.002105

[22] Gamson, W.A. (1989) News as Framing: Comments on Graber. American Behavioral Scientist, 33, 157-161. http://dx.doi.org/10.1177/0002764289033002006

[23] Schulte, S.R. (2012) The Political Power of Films: Traffic’s Impact on Drug Policy Debates. Southern Communication Journal, 77, 45-60. http://dx.doi.org/10.1080/1041794x.2011.578702

[24] Rogers, E.M. (2003) Diffusion of Innovations. 5th Edition, Free Press, New York.

[25] Centers for Disease Prevention and Control (2008) HIV/AIDS among Women. http://www.cdc.gov/hiv/topics/women/resources/factsheets/pdf/women.pdf

[26] Foxx, J. (Executive Producer) and George, N. (Director) (2007) Life Support. Foxx/King Entertainment/Flavor Unit Films, United States.

[27] Hooks, B. (1993) Sisters of the Yam: Black Women and Self-Recovery. South End Press, Boston.

[28] Centers for Disease Prevention and Control (2014) HIV among Women. http://www.cdc.gov/hiv/pdf/risk_women.pdf

[29] The Henry J. Kaiser Family Foundation (2006) HIV/AIDS Policy Fact Sheet. http://www.kff.org/hivaids/upload/6089-03.pdf

[30] Gollub, E.L. (2000) The Female Condom: Tool for Women’s Empowerment. American Journal of Public Health, 90, 1377-1381. http://dx.doi.org/10.2105/AJPH.90.9.1377

[31] Shervington, D.O. (1993) The Acceptability of the Female Condom among Low-Income African-American Women. Journal of the National Medical Association, 85, 341-347.

[32] PATH, UNFPA (2006) Female Condom: A Powerful Tool for Protection. Seattle. http://www.path.org/publications/files/RH female condom.pdf

[33] Herek, G.M. and Capitanio, J.P. (1999) AIDS Stigma and Sexual Prejudice. American Behavioral Scientist, 42, 1130-1147. http://dx.doi.org/10.1177/0002764299042007006

[34] The Henry J. Kaiser Family Foundation (2006) Kaiser Public Opinion Spotlight. http://www.kff.org/spotlight/hivstigma/upload/Spotlight_Aug06_Stigma-pdf

[35] Herek, G.M., Capitanio, J.P. and Widaman, K.F. (2002) HIV-Related Stigma and Knowledge in the United States: Prevalence and Trends, 1991-1999. American Journal of Public Health, 92, 371-377. http://dx.doi.org/10.2105/AJPH.92.3.371

[36] Lloyd, G.A. (1988) HIV-Infection, AIDS, and Family Disruption. In: Fleming, A.F., Carballo, M., FitzSimons, D.W., Bailey, M.R. and Mann, J., Eds., The Global Impact of AIDS, Alan R. Liss, Inc., New York, 183-190.

[37] Maman, S., Mbwambo, J.K., Hogan, N.M., Kilonzo, G.P., Campbell, J.C., Weiss, E. and Sweat, M.D. (2002) HIVPositive Women Report Lifetime Partner Violence: Findings from a Voluntary Counseling and Testing Clinic in Dar es Salaam, Tanzania. American Journal of Public Health, 92, 1331-1337. http://dx.doi.org/10.2105/AJPH.92.8.1331

[38] The Global Coalition on Women and AIDS (n.d.) Issue Brief: Stopping Violence against Women and Girls for Effective HIV Responses. http://www.womenandaids.net/CMSPages/GetFile.aspx?guid=c72d38e4-dfdb-441c-ad81-159866cc1491

[39] Millet, G., Malebranche, D., Mason., B. and Spikes, P. (2005) Focusing “Down Low”: Bisexual Black Men, HIV Risk and Heterosexual Transmission. Journal of the National Medical Association, 97, 52S-58S.

[40] Stokes, J.P., McKirnan, D.J., Doll, L. and Burzette, R.G. (1996) Female Partners of Bisexual Men: What They Don’t Know Might Hurt Them. Psychology of Women Quarterly, 20, 267-284. http://dx.doi.org/10.1111/j.1471-6402.1996.tb00470.x

[41] Rotheram-Borus, M.J., Flannery, D., Rice, E. and Lester, P. (2005) Families Living with HIV. AIDS Care, 17, $978-987$. http://dx.doi.org/10.1080/09540120500101690

[42] Yarhouse, M.A. (2003) Working with Families Affected by HIV/AIDS. The American Journal of Family Therapy, 31, 125-137. http://dx.doi.org/10.1080/01926180301124

[43] Vallerand, A.H., Hough, E., Pittiglio, L. and Marvicsin, D. (2005) The Process of Disclosing HIV Serostatus between HIV-Positive Mothers and Their HIV-Negative Children. AIDS Patient Care and STDS, 19, 100-109. http://dx.doi.org/10.1089/apc.2005.19.100

[44] Williams, S.E. (2003) HIV-Positive African American Women and Their Families: Barriers to Effective Family Cop- 
ing. In: Gilbert, D.J. and Wright, E.M., Eds., African American Women and HIV/AIDS Critical Responses, Praeger Publishers, Westport, 77-84.

[45] Moore, D., Onsomu, E.O. and Abuya, B.A. (2011) Entertainment-Education for Stating HIV/AIDS Discussions and Reducing Stigma: African American College Students' Reactions to the Film Yesterday. Journal of Best Practices in Health Professions Diversity: Research, Education and Policy, 4, 563-573.

[46] Foss, S.K., Foss, K.A. and Trapp, R. (2002) Contemporary Perspective on Rhetoric. 3rd Edition, Waveland Press, Inc., Prospect Heights. 
Scientific Research Publishing (SCIRP) is one of the largest Open Access journal publishers. It is currently publishing more than 200 open access, online, peer-reviewed journals covering a wide range of academic disciplines. SCIRP serves the worldwide academic communities and contributes to the progress and application of science with its publication.

Other selected journals from SCIRP are listed as below. Submit your manuscript to us via either submit@scirp.org or Online Submission Portal.
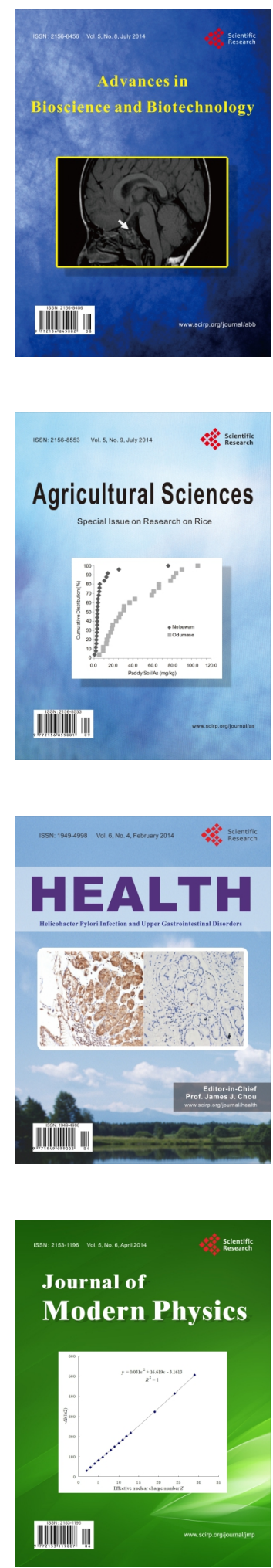
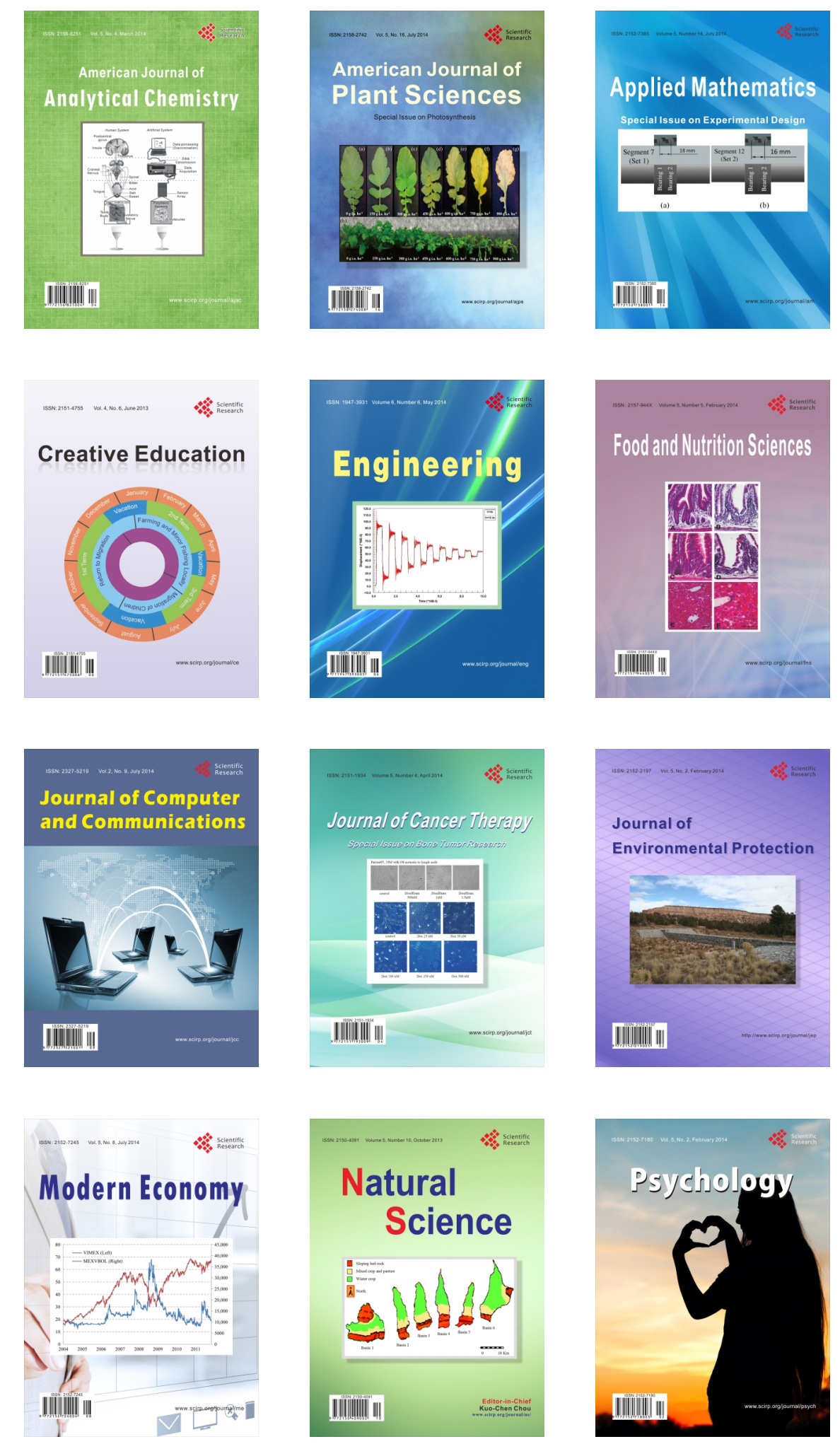